\title{
Investigating of Acute and Chronic Effects of Oxaliplatin on Rat Ocular Tissues
}

\author{
Akut ve Kronik Oksaliplatin Uygulamasının Sıçan Göz \\ Dokuları Üzerindeki Etkilerinin Araştırılması
}

\section{Özgün Araştirma Research Article}

Alındığı tarih: 31.07 .2019

Kabul tarihi: 02.10.2019 Online Yayın tarihi: 31.12.2019

Buket Demirci Aydın Adnan Menderes Üniversitesi, Tıp Fakültesi, Tibbi Farmakoloji Ana Bilim Dalı, Aydın - Türkiye

drbuketdemirci@gmail.com ORCID: 0000-0002-3442-5061

A.l. Akyuz Unsal 0000-0001-5260-647X Aydın Adnan Menderes Üniversitesi, Tıp Fakültesi, Göz Hastalıkları Ana Bilim Dalı, Aydın, Türkiye

F. Kahyaoglu 0000-0002-5149-8051 Manisa Celal Bayar Üniversitesi,

Tıp Fakültesi, Embriyoloji ve Histoloji Ana Bilim Dalı, Manisa, Türkiye

I. Saygin 0000-0002-6013-6378 Karadeniz Teknik Üniversitesi, Tıp Fakültesi, Tıbbi Patoloji Ana Bilim Dalı, Trabzon, Türkiye

O. Yersal 0000-0001-8220-4223 Aydin Adnan Menderes

Üniversitesi, Tıp Fakültesi, Tıbbi Onkoloji Ana Bilim Dalı, Aydın, Türkiye

Cite as: Akyuz Unsal Al, Kahyaoglu F, Saygın I, Yersal O, Demirci B. Investigating of acute I, Yersal O, Demirci B. Investigating of acute and chronic effects of oxaliplatin on rat ocular 2019;29(3):265-72.

\author{
Ayse Ipek Akyuz Unsal๑, Fadime Kahyaoglu $\odot$, Ismail Saygin $\odot$, Ozlem Yersal $\odot$, \\ Buket Demirci $\odot$
}

\section{ABSTRACT}

Objective: Visual disturbances occurring during cancer treatment with oxaliplatin (OXA) have been previously reported in some of case presentations. This study investigates the ocular toxicity of OXA on rat eye tissues by using histopathological staining. Additionally, the reversibility of findings, if there is any, were assessed in groups with waiting periods.

Method: Six-8 month-old rats have been separated into five groups. Acute OXA treatment (4 mg/ $\mathrm{kg}$ ) has been administered on days 1, 3 and $5^{\text {th }}$ days; consequently, the eye samples were obtained on $7^{\text {th }}$ and $14^{\text {th }}$ days of the study. Chronic OXA treatment ( $4 \mathrm{mg} / \mathrm{kg}$ ) has been administered for 4 weeks (two days of week); the rats were sacrificed on $28^{\text {th }}$ day and 21 days after completing administration of drug. One group was used as a control. Results: The most striking irreversible-features of OXA treatment were endothelial polypoid proliferation of the vessel, neo-vascularisation of cornea, capillarisation of optic nerve and, degeneration of retinal nerve fibre layer at several degrees of severity.

Conclusion: OXA treatment can be responsible for sight threatening side effects by influencing different parts of the ophthalmic system; therefore, oncologists and ophthalmologists should keep in mind the irreversibl-ophthalmic adverse effects of OXA treatment in oncology patients.

Keywords: Animal study, ophthalmology, oncology, rational drug use

Öz

Amaç: Oksaliplatin (OKSA) ile yapılan kanser tedavileri sırasında görme bozuklukları bir kaç olgu sunumunda bildirilmiştir. Bu çalışma histopatolojik boyama kullanarak sıçan göz dokularında oksaliplatinin göz toksisitesini araştırmaktadır. ilave olarak, eğer bir bulgu varsa, bulguların geri dönüşümlü olup olmadığı da bekleme süresi olan gruplarda değerlendirildi.

Yöntem: 6-8 aylık sıçanlar bes gruba ayrıldı. Akut OKSA tedavisi $(4 \mathrm{mg} / \mathrm{kg})$ 1., 3. ve 5. günlerde verildi, sonrasında, göz dokuları 7. ve 14. günde elde edildi. Kronik OKSA tedavisi (4 mg/kg), 4 hafta boyunca (hafta da 2 gün) uygulandı; sıçanlar 28. günde ve ilaç uygulamasının sonlandırılmasını takiben 21 gün beklenerek kesildi. Bir grup kontrol olarak kullanıldı.

Bulgular: OKSA tedavisinin en göze çarpan geri-dönüşümsüz bulguları, damar endotelinde polipoid proliferasyon, korneada yeni damar oluşumu, optik sinir kapillerlerinde artış ve retinal sinir lifi tabakasında farklı derecelerde dejenerasyondu.

Sonuç: OKSA tedavisi oftalmik sistemin farklı bölümlerini etkileyerek görmeyi tehtid eden yan etkilerden sorumlu olabilir, bu nedenle onkolog ve oftalmolog OKSA ile tedavi edilen onkoloji hastalarında geri dönüşümsüz oftalmik yan etkiler olabileceğini akılda bulundurmalıdır.

Anahtar kelimeler: Hayvan çalıșması, oftalmoloji, onkoloji, akılcı ilaç kullanımı

(c) Telif hakkı T.C. Sağlık Bakanlığı İzmir Tepecik Eğit. ve Araşt. Hastanesi. Logos Tıp Yayıncılık tarafindan yayınlanmaktadır. Bu dergide yayınlanan bütün makaleler Creative Commons Attf-GayriTicari 4.0 Uluslararası Lisansı ile lisanslanmısstır.

(c) Copyright Association of Publication of the T.C. Ministry of Health İzmir Tepecik Education and Research Hospital.

This journal published by Logos Medical Publishing.

Licenced by Creative Commons Attribution-NonCommercial 4.0 International (CC BY-NC 4.0) 


\section{INTRODUCTION}

Third generation platinum derivative, oxaliplatin (OXA), is frequently used as a standard therapy for colorectal cancer ${ }^{(1)}$. Expectedly, chemotherapeutic agents can have potential harmful effects on healthy tissues, but drug transportation to ocular tissues is not so easy due to natural barriers such as bloodretina ${ }^{(2)}$. Ocular toxicity of cisplatin (CIS) is well described previously ${ }^{(3,4)}$, but, there are very limited reports about the ocular side effects of OXA. Eye disorders including visual field defect, tunnel vision, visual field impairment, optic neuritis, papilledema and reduction in visual acuity have been reported as serious adverse effects of OXA ${ }^{(5,6)}$, however there are not any histopathologic findings and detailed safety studies about it.

In this study, ocular toxicity of OXA has been histopathologically assessed for acute and chronic term. Consequently, the adverse effect of the drug if there is any, was assessed for its reversibility with waiting period.

\section{MATERIAL AND METHODS}

\section{Animals and Experimental design}

Six-8 month-old male Wistar albino rats, were obtained from Animal Care and Research Unit of University and all experiments were performed according to the principles and guidelines of Animal Ethical Committee after receival of its approval. This study was mainly planned to evaluate the ototoxic effect of OXA, but lung, heart ${ }^{(7)}$ and eye tissues have been also evaluated with the aim to decrease the number of animal used in medical researches; after receiving relevant approval of the animal ethical committee (HADYEK, 64583101/2014/138). OXA (Eloxatin ${ }^{\circledR}$, Sanofi, U.S.), the dose of $4 \mathrm{mg} / \mathrm{kg}$ has been diluted in $5 \%$ glucose solution just prior to intraperitoneal (i.p.) administration. The experimental groups were as follows:
Control: The rats in this group were administered $5 \%$ glucose solution through intraperitoneal route.

Acute OXA treatment: Animals that received OXA treatment on the $1^{\text {st }}, 3^{\text {rd }}$ and $5^{\text {th }}$ days of the study, and were sacrificed on day 7 .

Acute OXA treatment + waiting period: Animals that received OXA treatment on the $1^{\text {st }}, 3^{\text {rd }}$ and $5^{\text {th }}$ days of the study, were sacrificed on day 14, to see the OXA effect one week later after drug cessation .

Chronic OXA treatment: OXA was administered two days a week (Monday and Thursday) for 4 weeks, then the rats were sacrificed on day 28.

Chronic OXA treatment + waiting period: OXA was administered two days a week (Monday and Thursday) for 4 weeks. Then the rats were sacrificed 21 days after the completion of the injections.

The tissue samples excised under the anesthesia of ketamine and xylazine $(50 \mathrm{mg} / \mathrm{kg}$ and $5 \mathrm{mg} / \mathrm{kg}$, respectively), were placed immediately in $10 \%$ formalin solution. After routine tissue following the obtained samples were sliced in 5 micrometer thickness and evaluated after hematoxylin-eosin (H-E) staining.

\section{RESULTS}

Histopathological analyses of all groups did not show uniform pathological phenomenon. Some photos of samples are shown in Figures 1-2, and 3. The prominent findings of the study were determined as endothelial polypoid proliferation of the vessel and neovascularisation of cornea, in addition to some degree of degeneration of retinal nerve fibre layer. Neovascularisation of cornea has increased in line with the duration of treatment. Similar pathological findings were also detected in optic nerve. Capillary vascular development was detected which increased by the duration of the treatment. The findings did not reverse properly, after 

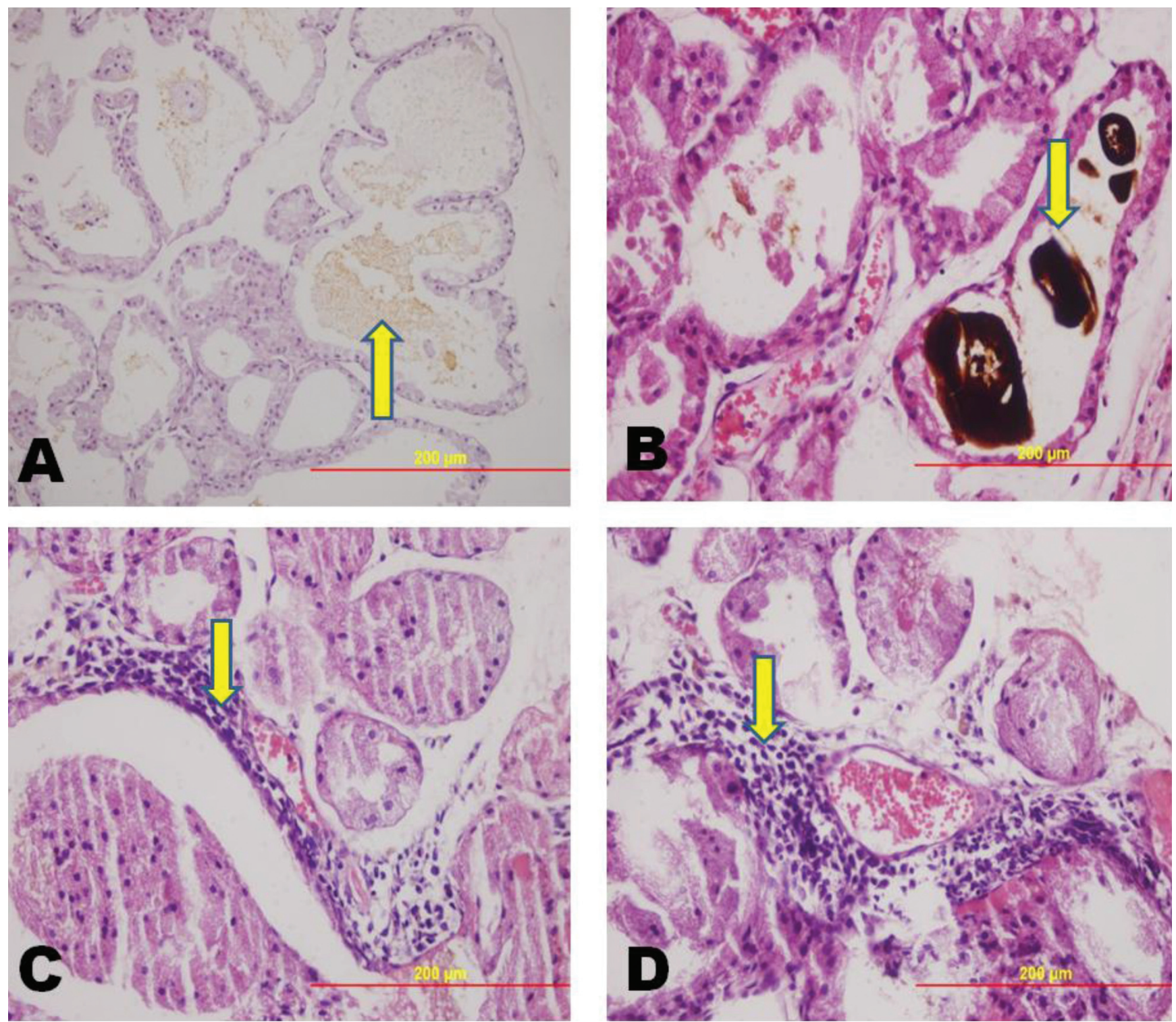

Figure 1.

A. Glandula lacrimalis cystic dilatation X40 HE (Acute OXA treatment + waiting period)

B. Glandula lacrimalis corpora amylacea X40 HE (Chronic OXA treatment + waiting period)

C. \& D. Glandula lacrimalis inflammation X40 HE (Chronic OXA treatment + waiting period) 

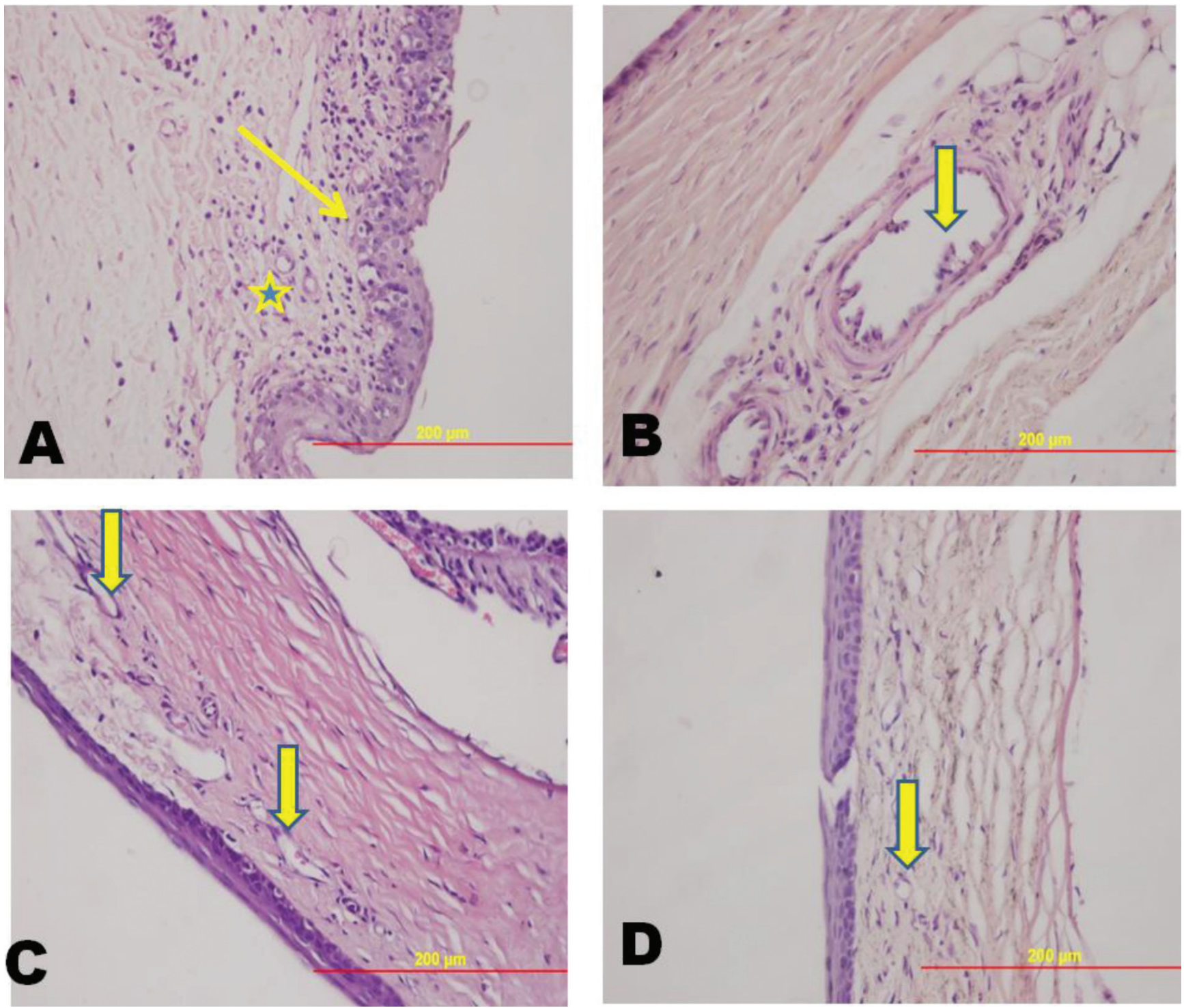

Figure 2.

A. Conjunctiva epithelial degeneration, basal vacuolar dilatation (arrow) with inflammatory cells (star) X40 HE (Chronic OXA treatment)

B. Endothelial polypoid proliferation of large vessel X40 HE (Acute OXA treatment + waiting period)

C. \& D. Corneal neo-vascularisation X40 HE (Acute OXA treatment + waiting period) 

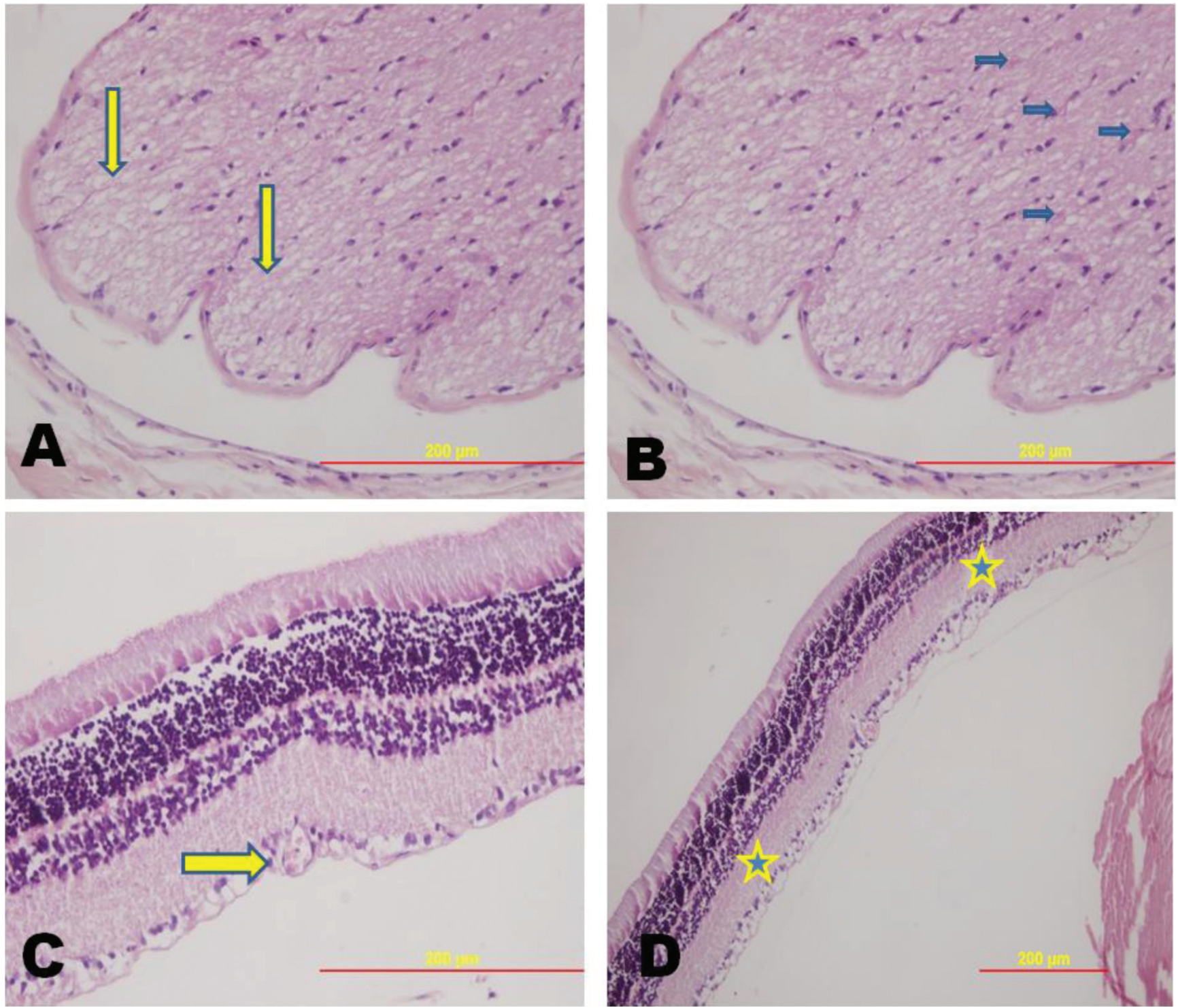

Figure 3.

A. Optic nerve vacuolar degeneration X40 HE (Acute OXA treatment)

B. Optic nerve capillarisation X40 HE (Acute OXA treatment).

C. Retinal nevre fibre layer degeneration X40 HE (Chronic OXA treatment)

D. Retinal nevre fibre layer vascularisation X20 HE (Chronic OXA treatment) 
Table 1. The histopathological findings of all experimental groups, number of pathologic sample/number of evaluated preparation.

\begin{tabular}{|c|c|c|c|c|c|}
\hline Findings & Control & $\begin{array}{l}\text { Acute OXA } \\
\text { treatment }\end{array}$ & $\begin{array}{l}\text { Acute OXA treatment } \\
\text { + waiting period }\end{array}$ & $\begin{array}{l}\text { Chronic OXA } \\
\text { treatment }\end{array}$ & $\begin{array}{c}\text { Chronic OXA treatment }+ \\
\text { waiting period }\end{array}$ \\
\hline \multicolumn{6}{|l|}{ Cornea } \\
\hline Neovascularization & $0 / 4$ & $4 / 9$ & $3 / 8$ & $6 / 8$ & $6 / 8$ \\
\hline \multicolumn{6}{|l|}{ Conjunctiva } \\
\hline Epithelial degeneration & $0 / 4$ & $0 / 9$ & $1 / 8$ & $2 / 8$ & $0 / 8$ \\
\hline \multicolumn{6}{|l|}{ Retina } \\
\hline Degeneration of retinal nerve fibre layer & $0 / 4$ & $2 \mathrm{M}, 2 \mathrm{~S} / 9$ & $3 \mathrm{M}, 1 \mathrm{~S} / 8$ & $5 \mathrm{M}, 3 \mathrm{~S} / 8$ & $3 M, 2 S / 8$ \\
\hline \multicolumn{6}{|l|}{ Vessel } \\
\hline Endothelial polipoid proliferation & $0 / 4$ & $3 / 9$ & $2 / 8$ & $4 / 8$ & $3 / 8$ \\
\hline \multicolumn{6}{|l|}{ Glandula Lacrimalis } \\
\hline Corpora amylacea & $3 / 4$ & $4 / 7$ & $2 / 4$ & $1 / 2$ & $5 / 7$ \\
\hline Cystic dilatation & $0 / 4$ & $2 / 7$ & $0 / 4$ & $0 / 2$ & $1 / 7$ \\
\hline Inflammatory cells & $0 / 4$ & $0 / 7$ & $0 / 4$ & $0 / 2$ & $1 / 7$ \\
\hline \multicolumn{6}{|l|}{ Optic Nerve } \\
\hline Inflammatory cells & $0 / 3$ & $0 / 6$ & $0 / 4$ & $0 / 6$ & $0 / 5$ \\
\hline Necrosis & $0 / 3$ & $0 / 6$ & $0 / 4$ & $0 / 6$ & $0 / 5$ \\
\hline Oedema & $0 / 3$ & $0 / 6$ & $0 / 4$ & $0 / 6$ & $0 / 5$ \\
\hline Number of seen capillary & $6-3-4$ & $3-4-3-3-0-0$ & $7-3-5-6-3$ & $4-4-6-8-9-3$ & $5-3-9-7-4$ \\
\hline Vacuolar degeneration & $0 / 3$ & $2 / 6$ & $1 / 5$ & $0 / 6$ & $0 / 5$ \\
\hline
\end{tabular}

Degeneration of retinal nerve fibre layer has been scored as medium $(+, M)$ and serious $(++, S)$. Capiller vascular number of each evaluated preparation given on the table (X40 magnification for evaluation.)

ceasing the treatment. All of the findings are summarized in Table 1.

\section{DISCUSSION}

The aim of the study was to investigate the safety of short-, and long-term OXA treatment on ocular tissues. Additionally, if there is any tissue damage, reversibility of the findings during waiting periods has been also investigated.

One of the advantages of animal studies is that only the effect of the suspected drug is evaluated. Considering many drugs taken altogether in a treatment regime, it is highly difficult to distinguish which one of them is responsible from the harmful effect. Also, synergistic effects of drugs can increase the number of unexpected adverse effects. In addition, the progression of cancer in the body can mimic or facilitate development of symptoms due to increased permeability of tissue barriers etc. While deciding the dose and duration of OXA in our animal study, we have taken previous literatures ${ }^{(8-11)}$, on OXA's animal neurotoxic study doses into account. Similar to our previous study ${ }^{(2)}$, we have evaluated all ocular tissue layers. Histopathological evaluation revealed many different pathological alterations in all parts of the ocular tissues; neo-vascularisation of cornea, endothelial polypoid proliferation of vessel and degeneration of retinal nerve fibre layer were important findings. These findings did not regress after discontinuation of OXA.

Noguchi et al., ${ }^{(6)}$ reported that the adverse effects of OXA frequently affect Japanese patients. Some of the symptoms appear at the early period of treatment that are reversible and mild in most cases. A 64-year-old woman developed blurred vision, transient bilateral temporal hemianopsia and progressive visual loss just three hours after administration of the drug and all of the visual symptoms were transient ${ }^{(1)}$. As, our study is an animal study, we could not describe any clinical findings such as blurred vision and pain, watering eyes; but, we could demonstrate histopathological findings of serious side effects of OXA on ophthalmic tissues. A case report of a 52 year-old woman describing visual loss, altered color vision and neurological symtoms under the advanced colorectal treatment, supports the findings of our study ${ }^{(12)}$. Her electrooculogram test revealed 
severe impairment of the retinal pigment epithelium and even after 8 months, electrooculogram remained abnormal. Park et al. have reported another 43-year-old woman, after one cycle of chemotherapy. This patient developed bilateral concentric field defect and electroretinogram revealed marked reduction of responses at both eyes and 3 months later electroretinogram still remained abnormal ${ }^{(1)}$. At some point, degeneration of retinal nerve fibre layer detected in this experimental study could explain the reported clinical findings.

Alterations in vascular cells were another remarkable finding of this study. The alterations have been determined as neo-vascularisation on cornea, endothelial polypoid proliferation of the vessel and increased capillary vessels of the optic nerve. Cisplatine induced neo-vascularization has been reported previously ${ }^{(3)}$; as another member of platinum derivatives OXA, induces neo-vascularisation irreversibly on eye tissues even during the acute-short term treatment.

The findings of glandula lacrimalis were not considered to be important because the development of corpora amylacea was also seen in the control group.

We preferred to describe the raw data of the each group on the Table 1; Statistical evaluation was not possible due to low number of preparations which could be evaluated. Hence, the changes of vascular cells and degeneration of retinal nerve fibre layer can be easier to follow in the different groups. This study is limited to one kind of staining technique, therefore it give us a general structural idea about the OXA side effects and its irreversible pattern on eye tissues in the studied posology. Additionally, except limited number of case reports, there is not any detailed study about the ocular effects of OXA, therefore we were unable to discuss our results from histopathological perspective. In other words, our study will shed the light on the future studies.

\section{CONCLUSION}

Ocular toxicity findings of OXA such as retinal nerve fibre degeneration and vascular alterations should be kept in mind in the clinical practice, during any treatment regimen. An irreversible damage on the ocular tissues may occur, if there is any suspicion, the patient should be referred to the ophthalmologist. Detailed reports also needed to clarify the severity and frequency of the ocular toxic effects of OXA.

Ethics Committee Approval: Animal Research Ethical Committee of Aydin Adnan Menderes University (HADYEK, 64583101/2014/138).

Conflict of Interest: Author declares no potential conflicts of interest with respect to the research, authorship, and/or publication of this article.

Funding: None.

Informed Consent: Not applicable.

Etik Kurul Onayı: Aydın Adnan Menderes Üniversitesi Hayvan Deneyleri Etik Kurulu (HADYEK, 64583101/2014/138).

Çıkar Çatışması: Yazar, bu makalenin araştırması, yazarı ve/veya yayınlanması ile ilgili olarak potansiyel çıkar çatışması beyan etmez.

Finansal Destek: Yok.

Hasta Onamı: Uygulanabilir değil.

\section{REFERENCES}

1. Wei-Yanhong, Xiang $\mathrm{H}, \mathrm{Du}$-Xiuping. A case of oxaliplatinreleated ocular toxicity. Clinical Case Reports International. 2017;1:1026.

2. Unsal AIA, Basal Y, Birincioglu S, Kocaturk T, Cakmak H, Unsal A, Cakiroz G, Eliyatkin N, Yukselen O, Demirci B. Ophthalmic adverse effects of nasal decongestants on an experimental rat model. Arquivos Brasileiros de Oftalmologia. 2018;81(1):53-8. [CrossRef]

3. Kwan AS, Sahu A, Palexes G. Retinal ischemia with neovascularization in cisplatin related retinal toxicity. Am J Ophthalmol. 2006;141(1):196-7. [CrossRef]

4. Langevin S, Chang JS, Chang S. Serous retinopathy associated with cisplatin treatment. Retin Cases Brief Rep. 2017; 22.

5. O'Dea D, Handy CM, Wexler A. Ocular changes with oxaliplatin. Clin J Oncol Nurs. 2006;10(2):227-9. [CrossRef]

6. Noguchi $Y$, Kawashima $Y$, Kawara H, Tokuyama $Y$, Tamura $Y$, 
Uchiyama K, Shimizu Y. A retrospective analysis of eye disorders due to oxaliplatin. GanTo Kagaku Ryoho. 2015;42(11):1401-5.

7. Eryilmaz U, Aksun S, Demirci B. The effect of oxaliplatin on heart tissue of the rats. J Clin Anal Med. 2018;9(1):9-12. [CrossRef]

8. Cavaletti, G. et al. Effects of different schedules of oxaliplatin treatment on the peripheral nervous system of the rat: Eur J Cancer. 2001;37(18):2457-63. [CrossRef]

9. Lim B S, Moon HJ, Li DX, Gil M, Min JK, Lee G, Bae H, Kim SK, Min BI. Effect of bee venom acupuncture on oxaliplatininduced cold allodynia in rats: Evid Based Complement Alternat Med, 2013; 2013: 369324. [CrossRef]
10. Moon HJ, Lim BS, Lee DI, Ye MS, Lee G, Min BI, Bae H, Na HS, Kim SK. Effects of electroacupuncture on oxaliplatin-induced neuropathic cold hypersensitivity in rats: J Physiol Sci. 2013. [CrossRef]

11. Yoon SY, Robinson CR, Zhang H, Dougherty PM. Spinal astrocyte gap junctions contribute to oxaliplatin-induced mechanical hypersensitivity: J Pain. 2013;14(2):205-14. [CrossRef]

12. Mesquida M, Sanchez-Dalmau B, Ortiz-Perez S, Pelegrín L, Molina-Fernandez J J, Figueras-Roca M, Casaroli-Marano R, Adán A. Oxaliplatin-related ocular toxicity. Case Reports in Oncology. 2010;3(3):423-7. [CrossRef]

13. Park HS, Kim YJ, Song SJ, Bae JH. A case of oxaliplatinreleated ocular toxicity. J Korean Ophthalmol Soc. 2014;55(1):143-8. [CrossRef] 